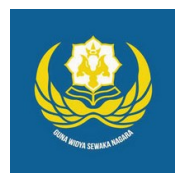

Jurnal Analogi Hukum

Journal Homepage: https://ejournal.warmadewa.ac.id/index.php/analogihukum

\title{
Kedudukan Pegawai Tidak Tetap (Tenaga Honorer) Setelah Berlakunya Undang-Undang Nomor 5 Tahun 2014
}

\author{
I Kadek Suryantara Bagus Wiranata*, Ida Ayu Putu Widiati dan I.PT.GD. Seputra \\ Universitas Warmadewa, Denpasar-Bali, Indonesia \\ *s.baguswiranata@gmail.com
}

\begin{abstract}
How To Cite:
Wiranata, I, K, S, B., Widiati, I, A, P., Seputra, I, P, G. (2020). Kedudukan Pegawai Tidak Tetap (Tenaga Honorer) Setelah Berlakunya UndangUndang Nomor 5 Tahun 2014. Jurnal Analogi Hukum, 2 (2). 176-181. Doi: https://doi.org/10.22225/ah.2.2.1917.176-181
\end{abstract}

\begin{abstract}
The enactment of Law Number 5 of 2014 concerning State Civil Apparatuses influences the position of temporary employees or honorary staff. The problem in this paper is how to regulate the legal status of nonpermanent employees after the enactment of Law Number 5 of 2014 concerning State Civil Apparatuses, as well as concerning legal protection of Temporary Employees (honorary workers) after the enactment of Law Number 5 of 2014 concerning Apparatus State Civil. To solve this problem, research is conducted using normative methods, sources of primary and secondary legal materials, methods of gathering legal materials using the recording of laws and other literature, and analyzing legal materials using legal arguments. The results of this study that the legal protection of Non-permanent Employees (honorary workers) after the enactment of Law Number 5 of 2014 concerning State Civil Apparatus is in Law Number 5 of 2014 concerning State Civil Apparatuses no longer found the term Permanent Employees or honorary employee. But when viewed from the classification of Civil Servants (PNS) and Government Employes with Work Agreements (PPPK). Based on Law Number 5 of 2014 concerning State Civil Apparatus Article 8 Government Employees with Work Agreements (PPPK) are located as one of the elements of the state apparatus. Legal protection for Non-permanent Employees (temporary workers) after the enactment of Law Number 5 of 2014 concerning State Civil Apparatus is protection in the form of old age insurance; health insurance; accident insurance; life insurance; and legal assistance. Protection in the form of old age insurance, health insurance, work accident insurance, and death insurance is carried out in accordance with the national social security system.
\end{abstract}

Keywords: Non-permanent employees, position, state civil apparatus

\begin{abstract}
Abstrak-Diundandangkanya Undang-undang Nomor 5 Tahun 2014 tentang Pegawai negeri Sipil Negara mepengaruhi posisi pegawai sementara atau staf kehormatan. Masalah dalam makalah ini adalah bagaimana mengatur status hukum karyawan tidak tetap setelah diberlakukan nya Undang-Undang Nomor 5 Tahun 2014 tentang Aparatur Sipil Negara, serta tentang perlindungan hukum terhadap Pegawai Sementara (pekerja honorer) setelah diberlakukan nya Undang-Undang Nomor 5 Tahun 2014 tahun 2014 tentang Aparatur Negara Sipil. Untuk mengatasi masalah ini, penelitian dilakukan dengan menggunakan metode normatif, sumber bahan hukum primer dan sekunder, metode pengumpulan bahan hukum menggunakan rekaman hukum dan literatur lainnya, dan menganalisis bahan hukum menggunakan argumen hukum. Hasil penelitian ini bahwa perlindungan hukum terhadap Pegawai Tidak Tetap (pekerja honorer) setelah berlakunya UndangUndang Nomor 5 Tahun 2014 tentang Aparatur Sipil Negara tidak lagi menemukan istilah Pegawai Tetap atau karyawan kehormatan. Namun jika dilihat dari klasifikasi Pegawai Negeri Sipil (PNS) dan Pegawai Pemerintah dengan Perjanjian Kerja (PPPK). Sebelum Undang-Undang Nomor 5 Tahun 2014 tentang Aparatur Sipil Negara Pasal 8 Pegawai Pemerintah dengan Perjanjian Kerja (PPPK) ditempatkan sebagai salah satu unsur aparatur negara. Perlindungan hukum bagi Pegawai Tidak Tetap (pekerja temporer) setelah berlakunya Undang-Undang Nomor 5 Tahun 2014 tentang Aparatur Sipil Negara adalah perlindungan dalam bentuk jaminan hari tua; asuransi kesehatan; asuransi kecelakaan; asuransi jiwa; dan bantuan hukum. Perlindungan dalam bentuk jaminan hari tua, asuransi kesehatan, asuransi kecelakaan kerja, dan asuransi kematian dilakukan sesuai dengan sistem jaminan sosial nasional.
\end{abstract}

Kata kunci: Pegawai tidak tetap, kedudukan, aparatur sipil negara

Jurnal Analogi Hukum, Volume 2, Nomor 2, 2020. CC-BY-SA 4.o License 


\section{Pendahuluan}

Ditengah perkembangan zaman menyebabkan kebutuhan manusia yang menjadi semakin beraneka ragam dan semakin komplek. Pemenuhan kebutuhan menjadi suatu alternatif sekaligus masalah. Setiap orang dituntut untuk bekerja dalam upaya memenuhi kebutuhan tersebut. Pada dasarnya pekerjaan tersebut seyogianya adalah pekerjaan yang memberikan seseorang untuk mengembayar dirinya sendiri dan diupayakan atas modal sendiri dengan berbagai tanggung jawab yang harus dihadapi. Bekerja merupakan suatu hal sentral dalam hidup manusia di berbagai kebudayaan, meskipun tidak dapat dipungkiri bahwa setiap budaya memiliki nilai dan konsepsi tersendiri dalam memaknai suatu pekerjaan (Anshori, 2013). Tetapi meskipun demikian tidak sedikit orang yang menggantungkan hidupnya dengan bekerja dengan orang lain. Ketika seseorang bekerja dengan orang lain maka orang tersebut harus tunduk dengan aturan perusahaan dan siap mengabdi dan loyal terhadap tempat kerjanya (Asikin, Zainal, Lalu Husni, \& Asyhadie, 2004). Rakyat Indonesia telah menyadari bahwa sebagaimana diatur dalam Pasal 27 ayat (2) Undang-undang Dasar Negara Republik Indonesia Tahun 1945 pekerjaan adalah kebutuhan dasar manusia bagi warga negara. Setiap warga negara memiliki hak untuk bekerja dan memiliki kehidupan yang layak seperti yang terdapat dalam Pasal 27 ayat (2) Undang-Undang Dasar Negara Republik Indonesia Tahun 1945. Artinya bahwa setiap orang yang menjadi warga negara Indonesia yang mampu dan bersedia untuk bekerja diberikan hak untuk bekerja yang dilindungi oleh hukum (Asikin et al., 2004).Dalam pengambilan keputusan untuk melakukan pelayanan-pelayanan umum maka penyelenggaraan pemerintahan daerah yang terdiri atas gubernur diberikan wewenang baik itu dalam bentuk wewenang yang independent ataupun wewenang yang dependen untuk mengambil keputusan dalam penyelenggaraan pelayanan kepada masyarakat. Kewenangan memiliki kedudukan penting dalam kajian hukum tata negara dan hukum administrasi (Hsb \& Julianthy, 2018). Wewenang terikat memiliki arti bahwa peraturan yang ada merupakan dasar dalam pengambilan keputusan atau disetiap tindakan berdasarkan aturan yang ada. Sedangkan wewenang bebas artinya adalah dikeluarkannya sebuah aturan oleh pemerintah aturan dasarnya memberikan kebebasan bagi pemerintah kepada penerima wewenang atau dengan kata lain tidak ada paksaan baku bagi pemerintah dalam menentukan isi keputusan yang akan dikeluarkan (Sadjijono, 2011).
Berdasarkan Undang-Unddang Nomor 32 Tahun 2004 yang diubah menjadi UndangUndang Nomo 12 Tahun 2008 tentang Perubahan Kedua atas Undang-Undang Nomor 32 Tahun 2004 tentang pemerintahan daerah mengatur dengan jelas terkait dengan implementasi kewenangan dari apartur sipil negara dalam memberikan pelayanan publik (Sadjijono, 2011).

Pemerintah seyogianya semakin giat dalam meningkatkan kinerjanya ditengah perkembangan ekonomi daerah sebagai implementasi atas pelaksanaan peraturan perundang-undangan yang ada. Upaya ini dilakukan agar kepentingan yang terdapat ditiap daerah mampu terakomodir dan dikelola dengan baik dan berbagai aspirasi masyarakat dapat terserap dengan baik sehingga akan mempercepat proses kesejahteraan yang merakyat bagi rakyat (M.Busrizalti, 2013). Keberadaan Sumber Daya Manusia yang bermutu dan berkualitas akan menentukan sukses atau tidaknya suatu pembangunan. Tujuannya adalah untuk menciptakan masyarakat yang adil dan makmur berdasarkan Pancasila dan Undang-Undang Dasar Negara Republik Indonesia Tahun 1945. Salah satu aparatur sipil negara yang memiliki fungsi dalam menjalankan fungsi pelayanan publik kepada masyarakat adalah pegawai, jadi ketika kita berbicara tentang posisi pegawai di Republik Indonesia, itu berarti kita berbicara tentang posisi Aparatur Negara secara umum, yang dalam GBHN, antara lain, menyatakan :

Aparatur Pemerintah sebagai Pegawai Negeri dan Pegawai masyarakat, semakin mengabdikan diri dan loyal kepada cita-cita perjuangan bangsa dan negara berdasarkan Pancasila dan Undang-Undang Dasar Negara Republik Indonesia Tahun 1945.

Pegawai Negeri Sipil sebagai salah satu unsur Aparatur Negara memiliki peran sebagai pelayan publik yang profesional, bermoral, memiliki kompetensi, taat terhadap peraturan yang ada serta mampu menjadi bagian dari menyampai aspirasi masyarakat kepada Pemerintah. Keberadaannya juga menjadi kebutuhan Pemerintah dalam menjalankan pembangunan suatu negara ada yang bersifat material dan non material, meskipun secara umum pembentukan dan implemetasikannya sumber daya manusia sebagai pengelolaan elemen manajemen.

Staf pegawai dalam pengembangannya bertujuan untuk membantu kinerja pegawai negeri sipil dimana pegawai negeri sipil sudah kewalahan dalam menjalankan fungsi-fungsi 
pemerintah daerah, salah satunya adalah dalam hal pelayanan publik yang merupakan fungsi dari Pemerintah Daerah itu sendiri. Staf pegawai memainkan peran penting untuk pelaksanaan layanan publik maksimum untuk masyarakat, karena layanan yang dilakukan tersebut akan dinilai oleh masyarakat (Dicky Agus Saputro, Sudarsono, Lutfi Effendi, 2014: $3)$.

Satu hal yang telah menarik perhatian belakangan ini adalah banyaknya pekerja yang disebut karyawan tidak tetap. Adapun yang dianggap sebagai pegawai tidak tetap adalah pegawai yang belum diangkat menjadi PNS atau Calon Pegawai Negeri Sipil (Djatmika, 1982).

Alasan untuk menerapkan staf tidak tetap itu sendiri lebih karena perekrutan dapat dilakukan dalam skala kecil atau besar-besaran. Ini juga didasarkan pada sejumlah besar lembaga pemerintah yang memerlukan staf tambahan sebagai bagian dari usaha untuk meningkatkan pemberian pelayanan yang prima kepada masyarakat.

Dalam Undang-Undang Nomor 43 Tahun 1999 tentang Prinsip-Prinsip Personil Pasal 2 ayat 3 menjelaskan bahwa selain PNS pemerintah juga berwenang menujuk pegawai tudak tetap sebagai pegawai sementara atau sebagai pegawai kontrak sebagai upaya dalam meningkatkan kualitas pelayanan serta membantu PNS dalam menjalankan tugas dan fungsinya.

Pasal 1 ayat 14 dalam Undnag-Undang Nomor 13 Tahun 2002 tentang Ketenagakerjaan menjelaskan bahwa perjanjian kerja digunakan sebagai dasr dari mengangkat seorang pegawai tidak tetap, dimana didalamnya dijelaskan tentang hubungan korelasi antara atasan dan bawahan. Lebih jauh arti dari atasan pasal 1 ayat 4. Majikan adalah seorang individu, pengusaha, badan hukum, atau badan lain yang mempekerjakan pekerja dengan membayar upah atau kompensasi dalam bentuk lain.

Dijelaskan bahwa yang mempekerjakan pekerja dengan membayar upah atau imbalan dalam bentuk apa pun juga dapat diartikan oleh siapa pun, yang mempekerjakan dan memberikan upah dapat disebut majikan. Dalam aturan Undang-Undang Ketenagakerjaan tepatnya di Pasal 59 ayat (1) mengenai perjanjian kerja dijelaskan bahwa:

pekerjaan yang diselesaikan sekali atau bersifat sementara;

pekerjaan yang diperkirakan selesai dalam waktu yang tidak terlalu lama dan maksimal 3 (tiga) tahun;

\section{pekerjaan musiman atau}

pekerjaan yang terkait dengan produk baru, kegiatan baru, atau produk tambahan yang masih diuji atau dieksplorasi.

Kini istilah pegawai tidak tetap atau honorere digantikan oleh pegawai pemerintah dengan penggunaan kontrak (PPPK). Hal ini sesuai dengan Undnag-Undang Nomor 5 Tahun 2014 tentang Apartur Sipil Negara. Tetapi staf kehormatan tidak dapat menjadi pegawai pemerintah menggunakan kontrak, mengingat untuk menjadi pegawai pemerintah yang menggunakan kontrak harus memiliki seleksi dan ujian sehingga pemerintah daerah tidak dapat secara sewenang-wenang merekrut pegawai pemerintah menggunakan kontrak dan harus mematuhi kebutuhan untuk mengingat bahwa pegawai pemerintah yang menggunakan kontrak memiliki hak yang sama sebagai Pegawai Negeri Sipil (PNS) dalam bentuk asuransi kesehatan dan lainnya sesuai dengan peraturan ketenagakerjaan.

Dengan diberlakukanya pegawai pemerintah dengan menggunakan kontrak, mau tidak mau pemerintah daerah harus menghapus keberadaan staf kehormatan sesuai dengan amanat UU No. 5 tahun 2014 tentang Aparatur Sipil Negara. Tapi ini tidak menciptakan keadilan bagi staf tidak tetap, terutama staf tidak tetap yang telah bekerja selama beberapa dekade berharap bahwa suatu hari mereka akan diangkat tetapi kini malah telah dihapuskan.

Isu yang diangkat dalam penelitian ini adalah beberapa hal sebagai berikut:

Kedudukan hukum seorang pegawai tidak tetap atau honorer berdasarkan Undang-Undang Nomor 5 Tahun 2014 tentang Aparatur Sipil Negara.

Perlindungan Hukum bagi pegawai tidak tetap dengan diberlakunya Undang-Undang Nomor 5 Tahun 2014 tentang Apartur Sipil Negara.

\section{Metode}

Metode yang digunakan dalam penelitian ini adalah hukum normatif, dengan penelitian evaluatif yang bertujuan untuk menilai pelaksanaan peraturan perundang-undangan dan dilakukan dengan melakukan penelitian perpustakaan dan penelitian lapangan (Fajar, 2010). Pendekatan masalah dalam penelitian ini menggunakan jenis pendekatan hukum. Bahan 
hukum yang digunakan meliputi bahan hukum primer dan bahan hukum sekunder. Metode pengumpulan bahan hukum yang digunakan untuk menyelesaikan masalah penelitian ini adalah dokumen normatif. Bahan hukum yang dikumpulkan dan diperoleh dianalisis secara sistematis, dalam bentuk deskripsi yang dikumpulkan dalam kalimat terstruktur dan kemudian secara sistematis dihubungkan untuk menarik kesimpulan untuk menjawab masalah dalam penelitian ini.

\section{Hasil Penelitian dan Pembahasan}

\section{Kedudukan Hukum Pegawai Tidak Tetap}

Pegawai tidak tetap atau pegawai honerer kini tidak ditemukan lagi istilah itu dalam Undang-Undang Nomor 5 Tahun 2014 tentang Aparatur Sipil negara. Namun jika dilihat dari klasifikasi Pegawai Negeri Sipil (PNS) dan Pegawai Pemerintah dengan Perjanjian Kerja (PPPK), mirip dengan karakteristik dari pegawai tidak tetap atau honorer tersebut, yaitu dimana di Pasal 1 disebutkan bahwa pegawai PPPK adalah pegawai yang tidak diangkat dan tidak memiliki nomor induk kepegawaian. Dari definisi ini, posisi karyawan tidak tetap adalah bagian dari aparatur negara atau aparatur negara dan memiliki peran memberikan layanan kepada masyarakat dengan cara yang profesional, jujur, adil dan adil.

Pada Undang-Undang Nomor 5 Tahun 2014 tentang Aparatur Sipil Negara dijelaskan bahwa di Pasal 10 seorang pegawai seyogianya mampu melaksanakan kebijakan yang ditetapkan oleh pimpinan dari instansi pemerintah serta terbebas dari intervensi atas golongan tertentu dan dari partai politik, serta dijelaskan sebagai berikut:

Pegawai ASN berfungsi sebagai pelaksana kebijakan publik; pelayan publik; dan perekat dan pemersatu bangsa.

Lebih lanjut dalam Pasal 11 disebutkan bahwa tugas yang dijalankan adalah terdiri atas:

Kebijakan dari Pegawai Pengawas Pegawai yang telah menetapkan kententuan peraturan perundang-undangan harus dilakukan oleh pegawai apatur sipil negara.

Pelayanan publik yang diberikan haruslah profesionel dan berkualitas.

Memperkuat Negara Kesatuan Republik Indonesia yang bersatu dan integritas.

Pada Pasal 12 dijelaskan bahwa:
Pegawai Aparatur Sipil Negara (ASN) berperan sebagai perencana, pelaksana, dan pengawas penyelenggaraan tugas umum pemerintahan dan pembangunan nasional melalui pelaksanaan kebijakan dan pelayanan publik yang profesional, bebas dari intervensi politik, serta bersih dari praktik korupsi, kolusi, dan nepotisme.

\section{Hak dan Kewajiban Pegawai Tidak Tetap}

Berdasarkan Undang-undang Nomor 5 Tahun 2014 tentang Aparatur Sipil Negara dalam Pasal 22 disebutkan bahwa hak-hak Pegawai Tidak Tetap yang digolongkan sebagai Pegawai Pemerintah dengan Perjanjian Kerja (PPPK) adalah sebagai berikut:

gaji dan tunjangan;

cuti;

perlindungan; dan

pengembangan kompetensi.

Beradasarkan Undang-Undang Nonomr 5 Tahu 2014 tentang Apartur Sipil Negara tepatnya di Pasal 23 disebutkan bahwa sebagai aparatur negara baik itu PNS maupun PPPK memiliki kewajban yang harus dijalankan yang terdiri atas:

Setia dan patuh kepada Pancasila, Undnagundang Dasar Negara Republik Indonesia Tahun 1945, negara dan pemerintah yang berdaulat.

Menjadi tali penyangga kesatuan dan persatuan bangsa.

Menjalankan kebijakan yang telah ditetapkan oleh pihak berwenang

Mematuhi peraturan perundang-undangan

Menjalankan tugas dengan penuh dedikasi, kejujuran, kesadaran dan tanggung jawab

Menunjukkan integritas dan mempu menjadi contoh bagi masyarakat.

Menyimpan rahasia tempat bekerja dan menjaga sikpa sesuai aturan perundangundangan.

Bersedia ditempatkan di seluruh wilayah tugasnya di Indonesia.

\section{Perlindungan Hukum Terhadap Pegawai Tidak Tetap}

Menurut Sudikno Mertokusumo, fungsi 
hukum sebagai pelindung kepentingan manusia untuk hukum itu harus dilaksanakan. Pelanggaran hukum yang terjadi merupakan salah satu dari alasan adanya tindakan yang dilakukan oleh pihak berwenang untuk melakukan penegakan hukum. Pelanggaran terhadap hukum yang berlaku akan menimbulkan suatu bentuk perlindungan terhadap subjek hukum yang ada di dalam perselisihan hukum yang sedang terjadi (Mertokusumo, 1996).

Perlindungan hukum tersebut adalah bentuk dari perlindungan terhadap hak asasi manusia yang tercantum dan ditetapkan dalam peraturan perundnag-undangan. Setiap manusia dijamin oleh hukum dan berhak mendapatkan perlindungan hukum yang bersifat adil dan merata tanpa memandang status atau kedudukan sesorang. Pelindungan hukum akan diberikan bagi sesorang yang merasakan bahwa kehidupannnya sedang dalam bahaya atau terdapat ancaman yang dimana setiap orang berhak mendapatkan rasa yang aman dalam menjalankan hidupnya sehari-hari tanpa adanya ancaman dari pihak manapun (Soeroso, 2005).

Oleh karena Pegawai negeri Sipil (PNS) memiliki banyak peran dan fungsi yang harus dijalankan, seringkali mereka mengalami kewalahan dalam menjalankan dan menyelesaikan tugasnya. Untuk dapat menjalankan tugas yang lebih efektif dan efisien serta bersikap profesional, jujur dan memiliki dedikasi kerja yang kompeten maka dalam menjalankan tugasnya PNS dibantu oleh pegawai tidak tetap atau honorer. Ha ini dilakukan sebagi upaya dari pemerintah untuk meningkatkan pemberian pelayanan kepada masyarakat. Harapannya adalah agar pelayanan publik yang dilakukan kepada masyarakat menjadi lebih baik, lebih berkualitas, cepat dan profesional.

Dengan adanya aturan Undang-Undang Nomor 5 tahun 2014 tentang Aparatur Negara maka keberdaan dari pegawai tidak tetap atau pegawai honorer menjadi dihapuskan keberadaannya dan digantikan kedudukannya menjadi Pegawai Pemerintah dengan Perjanjian Kerja (PPPK). Sebenarnya keduanya memiliki karateristik yang sama, tetapi harus ada kejelasan terhadap kedudukan pegawai yang sebelumnya dinyatakan sebagai pegawai tidak tetap atau pegawai honorer.

Undang-Undang Nomor 5 Tahun 2014 tentang Aparatur Sipil Negara telah membuat perubahan mendasar dalam peraturan negara, yang selanjutnya disebut sebagai karyawan ASN. Undang-Undang Nomor 5 Tahun 2014 tentang Aparatur Sipil Negara yang mengatur manajemen ASN menjadi Manajemen Pegawai Negeri Sipil (PNS) dan Manajemen Pegawai Pemerintah dengan Perjanjian Kerja (PPPK). Peraturan Umum Undang-Undang Nomor 5 Tahun 2014 tentang Aparatur Sipil PPPK adalah warga negara Indonesia yang memenuhi persyaratan tertentu, yang ditunjuk berdasarkan perjanjian kerja untuk jangka waktu tertentu untuk melaksanakan tugas pemerintahan. Dengan distribusi ini, Undang-Undang Nomor 5 Tahun 2014 tentang Aparatur Sipil Negara tidak hanya menerima pegawai pemerintah sebagai pegawai tetap, yaitu Pegawai Negeri Sipil (PNS), tetapi juga mulai memperkenalkan sistem kepegawaian baru mengenai pembayaran / kontrak kerja khusus, yaitu Pegawai Pemerintah dengan Perjanjian Kerja (PPPK).

Namun, UU Nomor 5 Tahun 2014 tentang Aparatur Sipil Negara tidak menjelaskan alasan dan kriteria mengenai pembagian manajemen PNS menjadi manajemen PNS dan PPPK. Harus ada perbedaan berdasarkan sifat dan jenis pekerjaan. Jika ini terkait dengan UU Ketenagakerjaan, perjanjian kerja untuk waktu tertentu tidak dapat diadakan untuk pekerjaan permanen (sementara).

Sifat masalah sementara diperjelas dengan batas waktu bagi karyawan kontrak. UndangUndang Ketenagakerjaan dalam hal ini mengatur perjanjian kerja berdasarkan jumlah yang dapat diambil untuk maksimum 2 (dua) tahun dan hanya dapat diperpanjang 1 (satu) kali untuk periode maksimum 1 (satu) tahun. Oleh karena itu, seseorang hanya dapat menjadi karyawan untuk jangka waktu maksimum 3 (tiga) tahun. Batas waktu 3 (tiga) tahun ini adalah sifat sementara dari suatu pekerjaan, jadi jika suatu pekerjaan dianggap tidak lengkap dalam 3 (tiga) tahun, maka pekerjaan itu akan menjadi permanen.

Keberadaan Undang-Undang Nomor 5 Tahun 2014 tentang Aparatur Sipil Negara menjelaskan bahwa PPPK memiliki kedudukan sebagai salah satu aparatur sipil negara dan ada kemungkinan mereka akan menjadi PNS. Namun harapan ini belum jelas mengingat belum dengan jelas ada di dalam peraturan perundang-undangan yang baru. Kejelasan mengenai sifat kesementaraan ini menimbulkan adanya ambiguitas persepsi. Pegawai tidak tetap atau yang sekarang disebut PPPK adalah sangat penting dalam mendukung pelayanan public kepada masyarakat. Tanpa adanya PPPK mungkin fungsi yang dijalankan oleh PNS atau beban kerja PNS akan menjadi sangat berat dan mereka akan menjalankan fungsi dan peran 
yang tidak dapat berjalan dengan profesional.

Berdasarkan Undang-Undang Nomor 5 Tahun 2014 tentang Aparatur Sipil Negara dalam Pasal 106 dinyatakan bahwa Pemerintah wajib memberikan perlindungan dalam bentuk:

$$
\begin{aligned}
& \text { jaminan hari tua; } \\
& \text { jaminan kesehatan; } \\
& \text { jaminan kecelakaan kerja; } \\
& \text { jaminan kematian dan } \\
& \text { bantuan hukum }
\end{aligned}
$$

Sistem jaminan secara nasional digunakan sebagai pedoman dalam pelaksanaan perlindungan terhadap PPPK dalam bentuk jaminan hari tua, asuransi kesehatan, asuransi kecelakaan kerja dan asuransi kematian. Apabila terjadi kasus-kasus yang tidak sesuai dengan kaidah yang terdapat dalam peraturan perundang-undangan maka akan diberikan bantuan hukum bagi PPPK terhadap kasuskasus yang terjadi sehubungan dengan menjalankan tugas dan kewajiabnnya.

\section{Simpulan}

Hasil analisis yang dilakukan memberikan beberapa gambaran terkait dengan permasalahan penelitian yang telah dirumuskan dalam rumusan permasalahan, dan dari uraian tersebut maka kesimpulan hasil penelitian adalah terdiri atas:

Berlakunya Undang-Undang Nomor 5 Tahun 2014 tentang Aparatur Sipil Negara menegaskan bahwa tidak lagi disebutkannya ada istilah pegawai tidak tetap atau honorer tetapi telah digantikan dengan istilah Pegawai Pemerintah dengan Perjanjian Kerja (PPPK). Hal ini sesuai dengan bunyi Pasal 1 yang menyebutkan bahwa PPPK adalah pengganti istilah dari tenaga kerja tidak tetap atau honorer, dimana PPPK adalah pegawai yang tidak ada pengangkatan dan tidak memiliki nomor induk kepegawaian. Dalam Pasal 8 dijelaskan bahwa kedudukan dari PPPK adalah sebagai bagian dari aparatur negara yang berfungsi memberikan pelayanan public kepada masyarakat secara profesional.

Berdasarkan Undang-Undang Nomor 5 Tahun 2014 tentang Aparatur Sipil Negara dijelaskan bahwa bentuk-bentuk perlindungan bagi PPPK adalah berupa perlindungan jaminan hari tua, jaminan kesehatan, jaminan kecelakaan kerja, jaminan kematian dan bantuan hukum. Pemerinat seyogianya mampu memenuhi hak-hak yang menjadi perlindungan bagi PPPK dalam menjalankan tugasnya agar dapat lebih prima dalam memberikan pelayanan kepada masyarakat.

\section{Daftar Pustaka}

Anshori, N. S. (2013). MAKNA KERJA (Meaning of Work) Suatu Studi Etnografi Abdi Dalem Keraton Ngayogyakarta Hadiningrat Daerah Istimewa Yogyakarta. Jurnal Psikologi Industri Dan Organisasi, 2(3), 157162.

Asikin, Zainal, A. W., Lalu Husni, \& Asyhadie, Z. (2004). Dasar-Dasar Hukum Perburuhan. Jakarta: Raja Grafindo Pustaka.

Djatmika. (1982). Sastra dan Marsono, Hukum Kepegawaian di Indonesia. Jakarta: Djambatan.

Fajar, M. (2010). Dualisme Penelitian Hukum Normatif dan Empiris. Yogyakarta: Pustaka Belajar.

Hsb, A. M., \& Julianthy, E. M. (2018). Pelaksanaan Kewenangan Atribusi Pemerintahan Daerah Berdasarkan Undang-Undang Nomor 23 Tahun 2014 Tentang Pemerintahan Daerah. Jurnal Legilasi Indonesia, 15(2), 1-8.

M.Busrizalti. (2013). Hukum pemda Otonomi Daerah dan Implikasinya. Total Media.

Mertokusumo, S. (1996). Mengenal Hukum suatu Pengantar. Yogyakarta: Liberty.

Sadjijono. (2011). Bab-Bab Hukum Administrasi. Yogyakarta: Laksbang Presindo.

Soeroso. (2005). Pengantar Ilmu Hukum. Jakarta: Sinar Grafika.

Undang - undang UU No. 13 Tahun 2003 Tentang Ketenagakerjaan.

Undang-Undang Nomor 5 Tahun 2014 tentang Aparatur Sipil Negara. 